\title{
Investigation into Particulate Pollutant Concentration From A Cement Plant: A Case Study Of Obajana Cement Plc, Lokoja, Nigeria
}

\author{
${ }^{1}$ Otaru, A.J., ${ }^{2}$ Odigure, J.O., ${ }^{3}$ Okafor, J.O. And ${ }^{4}$ Abdulkareem, A.S. \\ 1,2,3\&4 (Department of Chemical Engineering, Federal Univeristy of Technology, PMB 065, Gidan Kwanu, \\ Minna, Niger State, Nigeria).
}

(Published with the Support of Zeno Karl Schindler Foundation)

\begin{abstract}
The emission of particulate matter has been an integral part of the operations associated with the production of cement in Nigeria. This study plans to investigate the release of particulate pollutant concentration from Obajana cement plant in Nigeria. The meteorological concentrations of particulate matter have been measured by the Health and Safety Department of the cement plant using the SKC deployable particulate sampler at different locations of the plant for the year 2010 and 2011. The data obtained for the year 2010 are below the World Health Standard and Nigerian Federal Ministry of Environmental Standard of an annual average value of 260 and $500 \mu \mathrm{g} / \mathrm{Nm}^{3}$. Higher values of particulate pollutant concentrations were recorded for the year 2011. The maximum value of particulate matter recorded for this year is $448.16 \mu \mathrm{g} / \mathrm{Nm}^{3}$ which is below the Nigerian Federal Ministry of Environmental Standard and far above the World Health Standard. This may results from improper adoption of the control strategies or lower quality performance of the dust capturing devices. For these two years data obtained the cement plant operates below the Nigerian acceptable limits on particulate matter concentration.

Keywords: Air pollution, Cement plant, Environmental limit, Nigeria and Particulate matters.
\end{abstract}

\section{Introduction}

"We love this earth as the new born baby loves his mother's heart beat", hence there is the need to preserve the land, air and rivers for our children and our children's children. Therefore it is morally justifiable to ensure that the health and well being of the communities are not threatened by industrial emissions (Abdulkareem \& Odigure, 2009).

Undoubtedly, Cement is an indispensable ingredient for development, providing the "glue" that holds together much of the world's infrastructure (WBCSD, 2005). Ever since the great days of Rome, Cement has been considered as one of the most important building materials in the world. It is used in almost every country of the world. Because of the perishable nature of the product and the relatively high transportation cost, cement trade is limited. Therefore, Cement is produced in almost every country. Cement is often considered a key industry for a number of reasons. To begin with, cement is an essential input into the production of concrete, a primary building material for the construction industry. Cement production is not only a source of combustionrelated carbon dioxide emission; it is also one of industrial process-related emissions of greenhouse gases and particulate matter (U.S EPA, 2004).

The air pollution problems related to the production, handling, and transportation of Portland cement are caused by the very fine particles in the product. These fine particles are as a result of production steps which involves mining, crushing, and grinding of raw materials (principally limestone and clay); calcining the materials in a calciner: conversion of the material into clinker in a rotary kiln; cooling the resulting clinker in cooler (Grate Cooler); mixing the clinker with gypsum; and milling, and storing and bagging the finished cement. The process generates a variety of wastes, including dust, which may be captured and recycled to the process. The process is energy-intensive, and there are strong incentives for energy conservation. Gases from clinker cooler are used as secondary combustion air. The dry process using preheaters and precalciners is both economically and environmentally preferable to the wet process because the energy consumption is approximately half that for the wet process (Reding, 1977).

Air pollutants generated during the cement manufacturing process consist primarily of particulates from the raw and finished materials, and fuel combustion by-products. This dust comprises oxides of silicon, aluminium, iron, calcium, magnesium, potassium, and sulfur. Controlling particulates emissions from sources other than the kiln usually entails capturing the dust using a hood or other partial enclosure and transporting it through a series of dust devices to the collectors. The type of dust collector used is based on factors such as particle size, dust loading, flow rate, moisture content, and gas temperature (Reinhold, 1992). Electrostatic 
Precipitators (ESP) and Bag Filters (BF) are installed in dust emission locations of most Cement Plants in Nigeria.

Emissions of fine particulates from cement plant have manifold harmful effects to human health because they intrude deeply into the bronchi and even reach the pulmonary alveolus, and they weaken the self cleaning mechanism of the lungs. Additionally, respiratory malfunctions and deterioration of other diseases result in increased numbers of hospital admissions and emergency room visits, as well as increased mortality (BUWAL, 1996). Long range transport also occurs with fine particulates from natural sources and may even span over several kilometres and these would have a negative impacts not only on the host community but on the neighbouring towns and villages, states and the nation in general.

In order to limit the negative impacts of these pollutants from cement plant, the Nigeria Federal Ministry of Environmental (FMEv) and World Health Organization (WHO) have set standards to enable cement plant to improve on their dust capturing devices and comply within the accepted environmental standard. Failure to comply would be charged to court and fined. It is against this background that Investigation into Particulate Pollutant Concentration resulting from the largest Cement Producing Company in Africa is of Immense important. It would not only help the environmental ministries, agencies and other cement plants on what cleanup technique works but serve as a basis for future occurrence.

\section{Research Methodology}

There are various methods of detecting or monitoring air pollution in the environment. But these experimental methods are capital intensive; hence only large or well established industries can afford them. The research methodology presented herein is the one adopted and used by the Health and Safety Department of the aforementioned cement plant.

\subsection{Sampling}

The sampling was conducted by the Health and Safety staff of ESP mechanical department of the cement plant. This was carried out by replacing representative sample media used for calibration with new, preweighed media. Bracket was mounted at the desired location and at the breathing zone (6 ft or $2 \mathrm{~m}$ ) using wire ties or other fasteners. Impactor was mounted on screw on mounting brackets.

The screw was inserted on cap into screw hole in top of Impactor inlet and rotating the cap until it is tight. The pump was turn on and proper recording of sample start time, ambient temperature, ambient pressure, and other pertinent were done. After desired sample time has elapsed, the pump was turn off and sample stops time, total volume, ambient temperature, ambient pressure, and other pertinent data were recorded. The cap was removed, the calibration train was reinstated, and flow rate verified. Quick-disconnect on case were used to remove tubing from pump. Tubing and cap were removed from Impactor. The meteorological concentrations of particulate matter obtained are graphically presented in Figures.

\subsection{Particulate sampler}

The equipment used by the Health and Safety staff of ESP (Electrostatic Precipitator) mechanical department for particulate sampling at various locations in the plant is the SKC Deployable Particulate Sampler (DPS) System. The performance profile is indicated in Table 1. The SKC Deployable Particulate Sampler (DPS) System is a compact, portable, battery-operated, and cost-effective particulate sampling system that ensures the ability to monitor particulate matter (PM) in indoor and outdoor environments and in urban, industrial, or rural settings. The system features the fully programmable constant flow Leland Legacy ${ }^{\circledR}$ Sample Pump, the SKC DPS Impactor, and other equipment needed for effective ambient particulate sampling. All components are packaged in an easily carried heavy-duty Pelican ${ }^{\circledR}$ case from which the system operates.

The heart of the DPS System is the SKC DPS Impactor. This inertia Impactor is designed to remove particle larger than a specific cut-point (e.g., 2.5 or $10 \mu \mathrm{m}$ ) by capturing them on a disposal oiled impaction substrate that reduces particles bounce. Particles smaller than the cut-point are collected on a 47-mm filter. The DPS Impactor mounts easily and makes media changes fast and simple with its convenient removable filter cassette and opener. 
Table 1: Performance profile of the SKC Deployable Particulate Sampler

$\begin{array}{ll}\text { PERFORMANCE PROFILE } & \\ \text { Sampler: } & \text { SKC Deployable Particulate Sampler (DPS) System } \\ \text { Flow Rate: } & 10 \mathrm{~L} / \mathrm{min}( \pm 10 \%) \\ \text { 50\% Cut-point: } & 10 \mu \mathrm{m} \text { or } 2.5 \mu \mathrm{m} \\ \text { Run Time: } & >24 \text { hours on one battery charge } \\ \text { Power: } & \text { Rechargeable lithium-ion (Li-lon) battery, } 7.2 \mathrm{~V}, 10 \mathrm{Ah}\end{array}$

capacity

Recommended Impaction Substrates:

To reduce particle bounce: $37-\mathrm{mm}$ disposable pre-oiled porous plastic disk

For optional chemical analysis of larger particles: $37-\mathrm{mm}$ non-coated quartz or

PTFE (Teflon) filter, Non-coated filters do not reduce particle bounce.

Collection Filter:

Analysis:

Tubing:

Case Dimensions:

Complete System Weight:

Sampling Head (Impactor)

Dimensions:

Sampling Head (Impactor)

Weight: 47-mm quartz or PTFE with support ring

Gravimetric and chemical

3/8-in ID Tygon (supplied)

$18.5 * 14.1 * 6.9$ in $(47 * 36 * 18 \mathrm{~cm})$

$13.5 \mathrm{lbs}(6.1 \mathrm{~kg})$

2.6 dia. $* 1.8 \mathrm{D} * 3.8 \mathrm{~L}$ in $(7 * 5 * 10 \mathrm{~cm})$

$0.5 \mathrm{lb}(0.23 \mathrm{~kg})$

Note: The DPS System provides data similar to data from Federal Reference Method Samplers. The DPS System is not a Federal Reference Method sampler.

The SKC DPS System includes a Leland Legacy Sample Pump (5 to 15L/min) and charger, DPS Impactor, filter cassette, calibration adapter, cap, disposable impaction substrate (qty. 25), additional filter cassette, filter cassette opener, tubing, and mounting bracket in a heavy-duty lockable carry case. A laminar flowmeter is available in models 100-3900 and 100-3902 only.

\subsection{Principle of operation}

A sample pump draws particle-laden air at a flow of 10L/min through an inertial Impactor to separate airborne particles according to their aerodynamic diameter. Airflow enters the Impactor through eight nozzles on top of the sampler. The inlet nozzles are sized to operate at a $10 \mathrm{~L} / \mathrm{min}$ flow rate causing eight airjets to impinge onto the impaction substrate positioned below the inlet nozzles. Particle larger than the sampler cutpoint with enough inertia to cross the airstream lines impact on the impaction substrate. The airflow, containing smaller particles, makes a sharp turn, passes through the openings in the top of the filter cassette, and follows through to a 47-mm filter where the smaller particles collect.

The top of the filter cassette accommodate the impaction substrate. For optimum Impactor performance, a 37-mm oiled porous plastic disk is recommended as disposable collection substrate (supplied with system). Alternatively, if chemical analysis of the particles is desired, a 37-mm quartz or PTFE (Teflon) filter may be used. However, the use of non-coated impaction substrate may decrease the capture efficiency of particle larger than the cut-point.

\subsection{Media preparation}

Collection Filters: Equilibrate and pre-weigh filters in a clean environment according to appropriate procedures. Record the weight as the pre-sample weight.

Impaction Substrate: Saturate a 37-mm porous plastic disk with oil. Using an oiled impaction substrate reduces a particle bounce. Non- coated 37-mm quartz or PTFE (Teflon) filters may be used if chemical analysis of larger particle is desired, however, use of a non-coated filter for impaction substrate will increase particle bounce.

\subsection{Cleaning}

For optimum performance, the DPS Impactor inlet, exhaust, and filter cassette should be cleaned after five runs or upon a noticeable build-up of material to remove oil build-up on the top of the filter cassette and other residue built up from frequent sampling. Disassemble the Impactor and wash parts in water with a liquid detergent or soap. Rinse and air-dry all parts thoroughly in a clean environment. 


\subsection{Removing the pump for battery charging}

Remove the sample pump from the case by gently pulling it to the left and lifting it out. Once the battery is charged, replace pump in foam section, align the inlet with the tubing, and gently push it to the right until the tubing is sealed firmly around the pump inlet.

\subsection{Technical titbits}

Cap should be used for all environmental sampling.

Keep Leland Legacy sample pump inside the Pelican case during sampling to protect sample pump from weather.

\section{Results And Discussion}

The impacts of gas flaring and particulate emissions are of local and global environmental concern (Ajayi, 1999). Suspended particulate matter from cement plant, adversely affect the health of human and animals and also causes plant and material damage. Two years data collated from various section of Obajana cement plant in Nigeria are presented in graphical forms. The sections of the plant are clinker extraction area (CEA), kiln (KL), mix storage (MS), packing plant (PCP) and cement mill (CM).

\subsection{Environmental SPM for the year 2010}

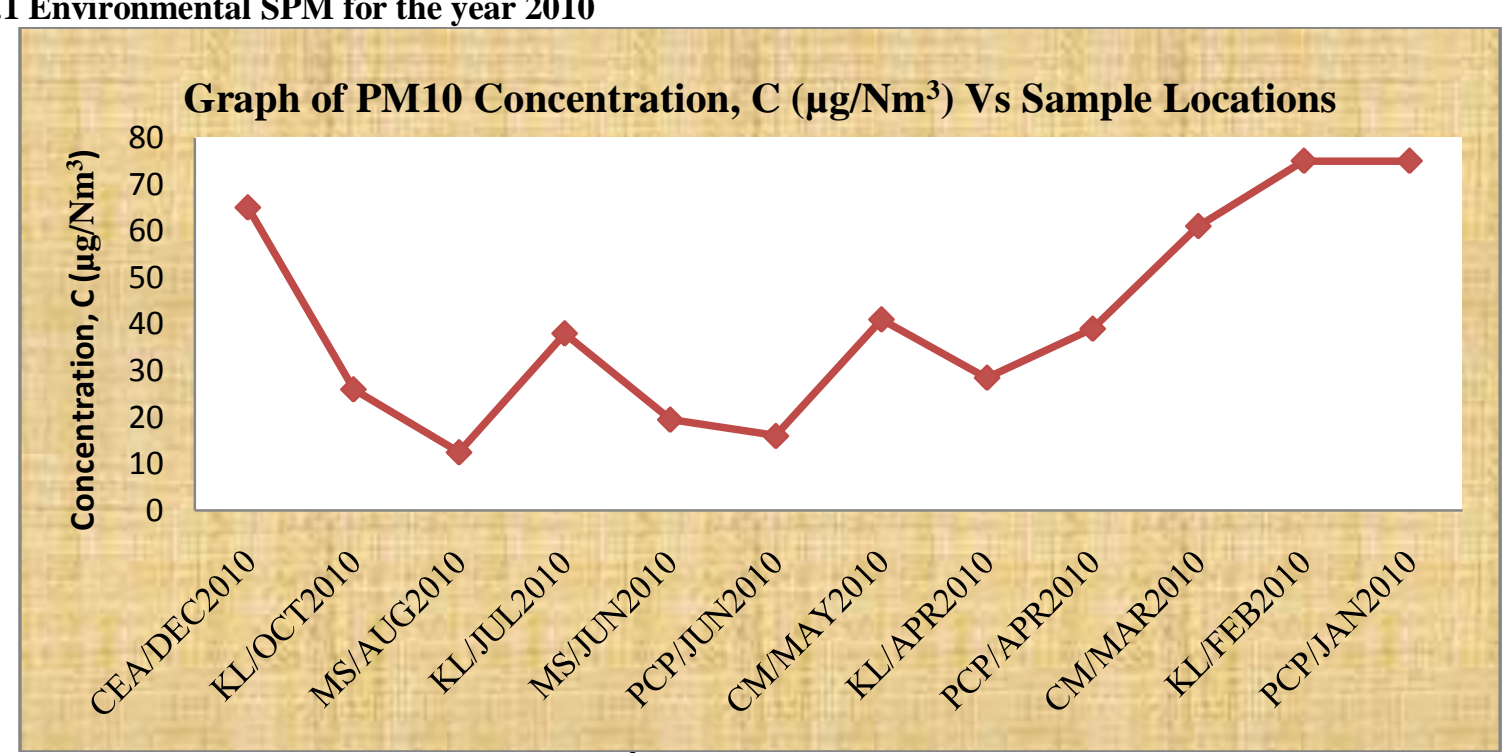

Figure 1: Ambient Air Quality $\left(\mu \mathrm{g} / \mathrm{m}^{3}\right)$ Vs Sample Location (December, 2010-January, 2010)

Figure 1 is the in-house Environmental Respirable Suspended Particulate Matter (SPM) for the year 2010. Higher concentrations of particulate matters were obtained in the clinker extraction, kiln, packing plant and cement mill locations. This is attributed to the fact that the plant may still be in operation when the sampling is taking. High dust is usually noticed when the plant is in operation compared with when there is a shut down for maintenance. Also, high concentration of particulate matter observed in the packing plant location for the month of January may be attributed to vehicular movement and lack of rainfall. Lower concentration in the mix storage for June and August may be due to high rainfall that would have eased the movement of vehicles or an evidence of water sprinkled in the locations.

Figure 2 is the in-house Environmental Respirable Suspended Particulate Matter (SPM) for the year 2011. 


\subsection{Environmental SPM for the year 2011}

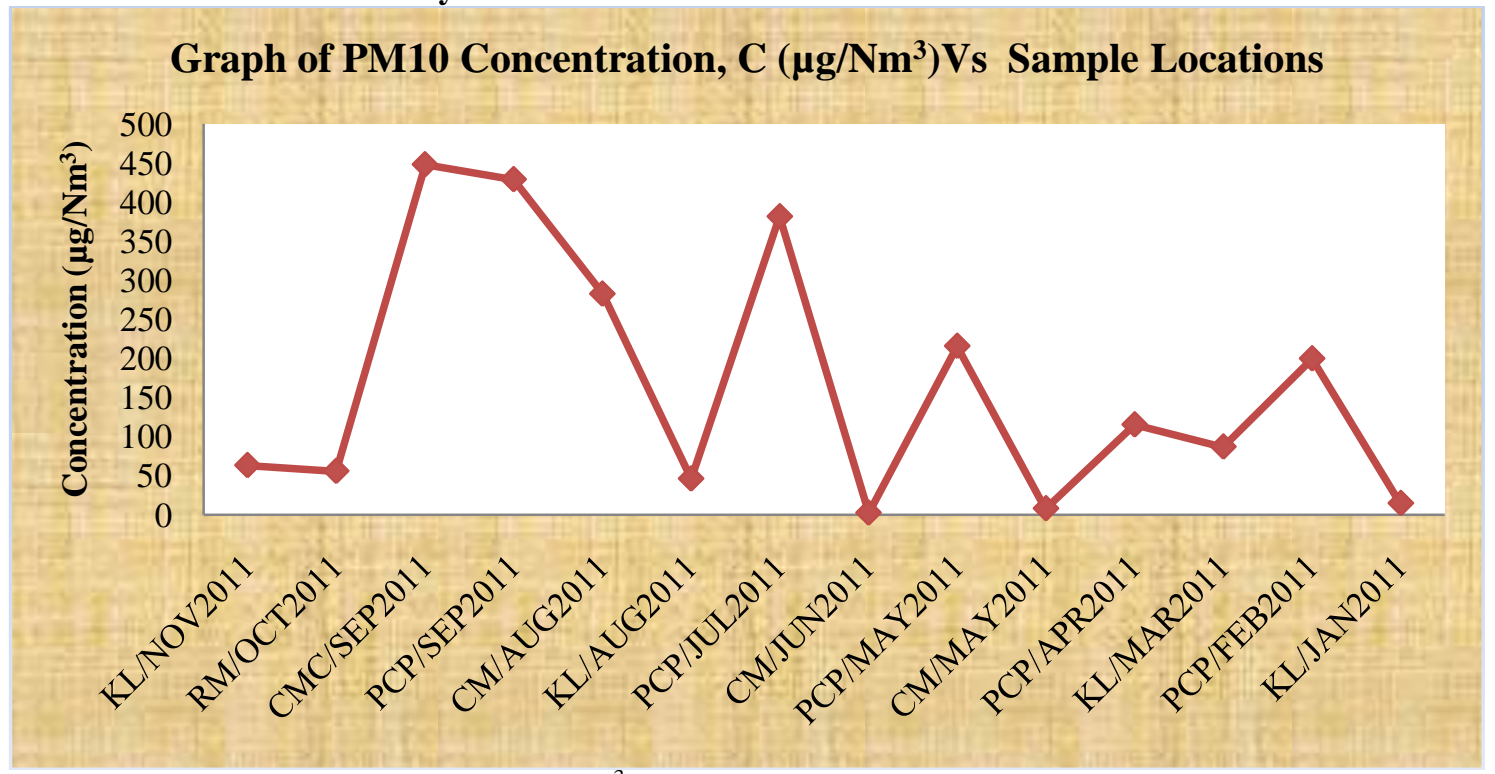

Figure 2: Ambient Air Quality $\left(\mu \mathrm{g} / \mathrm{m}^{3}\right)$ Vs Sample Location (November, 2011-January, 2011)

The maximum particulate concentration of $448.16 \mu \mathrm{g} / \mathrm{m}^{3}$ in the year 2011 may be an indication on the lack of water sprinkled in the cement mill section and dusts from packaging plant caused by vehicular movements. Though, they show that all the particulate concentrations are below the Nigerian Federal Ministry of Environmental acceptable limit of $500 \mu \mathrm{g} / \mathrm{Nm}^{3}$ but it is far above the World Health Organisation (WHO) Standard of Annual Average Value of $260 \mu \mathrm{gN} / \mathrm{m}^{3}$.

The particulate pollutant concentrations obtained at various locations of the plant (mix-storage department, packing plant, cement silo, kiln, and clinker extraction area) for a period of two years and the control strategies adopted to ensure the company operates within the environmental acceptable limited are collaborated and presented in Table 2 and 3.

\subsection{Environmental Respirable Suspended Particulate Sampling For The Year 2010 And 2011.}

\section{YEAR 2010}

Air flow rate: $10 \mathrm{~L} / \mathrm{min}$.

Equipment for Ambient Temperature: Digital Pyrometer.

APR: Ambient Particulate Result.

AT: Ambient Temperature $\left({ }^{\circ} \mathrm{C}\right)$.

ST: Sampling Time (min).

SE: Sampling Equipment (SKC Deployable Particulate Sampler).

SM: Sampling Method (PM 10 Particulate Sampling)

SL: Sampling Location

RAPL: Regulatory Ambient Particulate Limit $\left(260 \mu \mathrm{g} / \mathrm{Nm}^{3}\right.$ for $\mathrm{WHO}$ and $500 \mu \mathrm{g} / \mathrm{Nm}^{3}$ for FMEv).

Table 2: Ambient air quality for the year 2010

\begin{tabular}{llllllll}
\hline S/No & DATE & TIME & $\begin{array}{l}\text { AT } \\
\left({ }^{\circ} \mathrm{C}\right)\end{array}$ & $\begin{array}{l}\text { ST } \\
(\mathrm{min})\end{array}$ & $\begin{array}{l}\text { SAMPLING } \\
\text { LOCATION }\end{array}$ & $\begin{array}{l}\text { APR } \\
\left(\mu \mathrm{g} / \mathrm{Nm}^{3}\right)\end{array}$ & REMARK \\
\hline 1 & $15 / 12 / 2010$ & $8: 30 \mathrm{am}$ & 27.00 & 240 & $\begin{array}{l}\text { Clinker } \\
\text { Extraction area } \\
\text { (CEA) }\end{array}$ & 65.00 & $\begin{array}{l}\text { Result complied with regulatory } \\
\text { limit. }\end{array}$ \\
2 & $30 / 11 / 2010$ & $8: 00 \mathrm{am}$ & 28.00 & 300 & $\begin{array}{l}\text { Clinker } \\
\text { Extraction area } \\
(\mathrm{CEA}) \\
\text { Kiln area (KL) }\end{array}$ & 26.00 & $\begin{array}{l}\text { Result complied with regulatory } \\
\text { limit, but relatively high. }\end{array}$ \\
4 & $12 / 10 / 2010$ & $8: 00 \mathrm{am}$ & 29.00 & 300 & $\begin{array}{l}\text { Result complied with regulatory } \\
\text { limit. } \\
\text { Result complied with regulatory } \\
\text { limit. }\end{array}$ \\
\hline
\end{tabular}




\begin{tabular}{|c|c|c|c|c|c|c|c|}
\hline 5 & $22 / 07 / 2010$ & 9:00am & 30.00 & 300 & Kiln area $(\mathrm{KL})$ & 38.00 & $\begin{array}{l}\text { Result complied with regulatory } \\
\text { limit, however elevated ambient } \\
\text { dust level was due to re-bricking } \\
\text { works going on at the Kiln line -. }\end{array}$ \\
\hline 6 & $25 / 06 / 2010$ & 9:00am & 28.00 & 300 & $\begin{array}{l}\text { Mix Storage } \\
\text { area }(\mathrm{MS})\end{array}$ & 19.50 & $\begin{array}{l}\text { Result complied with regulatory } \\
\text { limit. }\end{array}$ \\
\hline 7 & $01 / 06 / 2010$ & 9:00am & 29.00 & 300 & $\begin{array}{l}\text { Packing Plant } \\
\text { area (PCP) }\end{array}$ & 16.00 & $\begin{array}{l}\text { Result complied with regulatory } \\
\text { limit. }\end{array}$ \\
\hline 8 & $14 / 05 / 2010$ & 9:00am & 28.00 & 300 & $\begin{array}{ll}\text { Cement } & \text { Mill } \\
\text { area }(\mathrm{CM}) & \end{array}$ & 41.00 & $\begin{array}{l}\text { Result complied with regulatory } \\
\text { limit. }\end{array}$ \\
\hline 9 & $21 / 04 / 2010$ & 9:00am & 29.00 & 300 & Kiln area $(\mathrm{KL})$ & 28.50 & $\begin{array}{l}\text { Result complied with regulatory } \\
\text { limit. }\end{array}$ \\
\hline 10 & 06/04/2010 & 9:30am & 29.00 & 300 & $\begin{array}{l}\text { Packing Plant } \\
\text { area (PCP). }\end{array}$ & 39.00 & $\begin{array}{l}\text { Result complied with regulatory } \\
\text { limit. Considerable reduction in } \\
\text { dust level caused by the recent } \\
\text { rainfall. }\end{array}$ \\
\hline 11 & $22 / 03 / 2010$ & 9:00am & 28.00 & 300 & $\begin{array}{ll}\text { Cement } & \text { Mill } \\
\text { area }(\mathrm{CM}) & \end{array}$ & 61.00 & $\begin{array}{l}\text { Result complied with regulatory } \\
\text { limit. Dust cloud induced by } \\
\text { vehicular movements at the air } \\
\text { sampling location. }\end{array}$ \\
\hline 12 & $16 / 02 / 2010$ & 9:30am & 29.00 & 420 & Kiln area $(\mathrm{KL})$ & 75.00 & $\begin{array}{l}\text { Result complied with regulatory } \\
\text { limit. Increased in dust } \\
\text { concentration results from } \\
\text { increased sampling time. }\end{array}$ \\
\hline 13 & $19 / 01 / 2010$ & 9:00am & 27.00 & 360 & $\begin{array}{l}\text { Packing Plant } \\
\text { area (PCP) }\end{array}$ & 75.00 & $\begin{array}{l}\text { Result complied with regulatory } \\
\text { limit, but relatively high due to } \\
\text { vehicular movement around the } \\
\text { packing plant area. }\end{array}$ \\
\hline
\end{tabular}

\section{YEAR 2011}

Air flow rate: $10 \mathrm{~L} / \mathrm{min}$.

Equipment for Ambient Temperature: Digital Pyrometer.

APR: Ambient Particulate Result.

AT: Ambient Temperature $\left({ }^{\circ} \mathrm{C}\right)$.

ST: Sampling Time (min).

SE: Sampling Equipment (SKC Deployable Particulate Sampler).

SM: Sampling Method (PM 10 Particulate Sampling)

SL: Sampling Location

RAPL: Regulatory Ambient Particulate Limit $\left(260 \mu \mathrm{g} / \mathrm{Nm}^{3}\right.$ for WHO and $500 \mu \mathrm{g} / \mathrm{Nm}^{3}$ for FMEv).

Table 3: Ambient air quality for the year 2011.

\begin{tabular}{|c|c|c|c|c|c|c|c|}
\hline S/No & DATE & TIME & $\begin{array}{l}\text { AT } \\
\left({ }^{\circ} \mathrm{C}\right)\end{array}$ & $\begin{array}{l}\text { ST } \\
(\mathrm{min})\end{array}$ & $\begin{array}{l}\text { SAMPLING } \\
\text { LOCATION }\end{array}$ & $\begin{array}{l}\text { APR } \\
\left(\mu \mathrm{g} / \mathrm{Nm}^{3}\right)\end{array}$ & REMARK \\
\hline 1 & $08 / 11 / 2011$ & 9:20am & 27.00 & 360 & Kiln area (KL) & 63.50 & $\begin{array}{l}\text { Result complied with regulatory } \\
\text { limit. }\end{array}$ \\
\hline 2 & $17 / 10 / 2011$ & 9:30am & 28.00 & 360 & $\begin{array}{l}\text { Raw Mill area } \\
(\mathrm{RM})\end{array}$ & 56.10 & $\begin{array}{l}\text { Result complied with regulatory } \\
\text { limit. }\end{array}$ \\
\hline 3 & $27 / 09 / 2011$ & 9:00am & 28.7 & 360 & $\begin{array}{l}\text { Cement Mill area } \\
(\mathrm{CM})\end{array}$ & 448.16 & $\begin{array}{l}\text { Result not complying with } \\
\text { regulatory limit due to heavy } \\
\text { vehicular movement around the } \\
\text { cement mill area. }\end{array}$ \\
\hline 4 & $01 / 09 / 2011$ & $8: 35 \mathrm{am}$ & 25.30 & 360 & $\begin{array}{l}\text { Packing } \\
\text { area (PCP) }\end{array}$ & 429.17 & $\begin{array}{l}\text { Result not complying with } \\
\text { regulatory limit, due to cement } \\
\text { loading \& high dust turbulence due } \\
\text { to truck movement. }\end{array}$ \\
\hline 5 & $25 / 08 / 2011$ & 8:31am & 24.90 & 360 & $\begin{array}{l}\text { Cement Mill area } \\
\text { (CM) }\end{array}$ & 282.77 & $\begin{array}{l}\text { Result not complying with } \\
\text { regulatory limit, due to high dust } \\
\text { emission from the bag house \& } \\
\text { high dust turbulence due to truck } \\
\text { movement. }\end{array}$ \\
\hline 6 & $16 / 08 / 2011$ & 8:30am & 31.40 & 360 & Kiln area $(\mathrm{KL})$ & 46.39 & $\begin{array}{l}\text { Result complying with regulatory } \\
\text { limit. }\end{array}$ \\
\hline
\end{tabular}




\begin{tabular}{|c|c|c|c|c|c|c|c|}
\hline 7 & 19/07/2011 & 9:00am & 26.00 & 300 & $\begin{array}{l}\text { Packing Plant } \\
\text { area }(\mathrm{PCP})\end{array}$ & 381.67 & $\begin{array}{l}\text { Result not complying with } \\
\text { regulatory limit due to high dust } \\
\text { emission from bag house \& high } \\
\text { dust turbulence due to truck } \\
\text { movements. }\end{array}$ \\
\hline 8 & $28 / 06 / 2011$ & 9:00am & 27.00 & 360 & $\begin{array}{l}\text { Cement Mill area } \\
(\mathrm{CM})\end{array}$ & 2.77 & $\begin{array}{l}\text { Result complied with regulatory } \\
\text { limit. }\end{array}$ \\
\hline 9 & $23 / 05 / 2011$ & 9:00am & 27.00 & 360 & $\begin{array}{l}\text { Packing Plant } \\
\text { area }(\mathrm{PCP})\end{array}$ & 216.00 & $\begin{array}{l}\text { Result showing elevated dust level, } \\
\text { though complying with regulatory } \\
\text { limit. }\end{array}$ \\
\hline 10 & $16 / 05 / 2011$ & $9: 15 \mathrm{am}$ & 26.00 & 360 & $\begin{array}{l}\text { Cement Mill area } \\
(\mathrm{CM})\end{array}$ & 8.33 & $\begin{array}{l}\text { Result complied with regulatory } \\
\text { limit. }\end{array}$ \\
\hline 11 & $19 / 04 / 2011$ & 9:00am & 27.00 & 360 & $\begin{array}{l}\text { Packing Plant } \\
\text { area }(\mathrm{PCP})\end{array}$ & 115.56 & $\begin{array}{l}\text { Result complied with regulatory } \\
\text { limit, though high value of dust } \\
\text { level recorded was due to dust- } \\
\text { cloud induced by vehicular } \\
\text { movements at the packing plant } \\
\text { location. }\end{array}$ \\
\hline 12 & 28/03/2011 & 8:30am & 29.00 & 360 & Kiln area $(\mathrm{KL})$ & 87.25 & $\begin{array}{l}\text { Result complied with regulatory } \\
\text { limit }\end{array}$ \\
\hline 13 & $28 / 02 / 2011$ & 8:30am & 28.00 & 300 & $\begin{array}{l}\text { Packing Plant } \\
\text { area }(\mathrm{PCP})\end{array}$ & 200.00 & $\begin{array}{l}\text { Result complied with regulatory } \\
\text { limit, but relatively high due to } \\
\text { vehicular movement around the } \\
\text { packing plant area. }\end{array}$ \\
\hline 14 & 07/01/2011 & 8:00am & 28 & 300 & Kiln area (KL) & 15.00 & $\begin{array}{l}\text { Result complied with regulatory } \\
\text { limit. }\end{array}$ \\
\hline
\end{tabular}

\section{Mitigation Measures}

1. Optimizing of Gas Conditioning Tower (GCT) and Electrostatic Precipitators (ESP) performance and improvement of speed limits for vehicle at operational site.

2. Improved housekeeping and implementation of speed limits for vehicles at operational sites.

3. Regular water sprinkling of the packing plant.

4. Mass replacement of defective bag filters in the Cement Mill bag house.

5. Improved maintenance of bag filters coupled with rains.

6. Regulatory water sprinkling and effective combustion process control.

7. Truck to observe speed limits and regular sprinkling of water around the Weigh (WF) feeder area.

8. Improved maintenance of dust control equipment and house keeping at the cooler ESP areas.

9. Modification of the de-dusting chutes installed at the clinker extraction area to allow for greater suction, and uniform materials flow in the direction of belt motion.

10. Entering speed limits for vehicular movements at the kiln area will help minimize dusts turbulence.

11. Water sprinkling to be intensified and natural reduction in atmospheric fog by atmospheric air dispersion will reduce.

\section{Conclusion}

A detailed investigation on the release of particulate pollutant concentration dispersed within Obajana cement plant in Nigeria was carried. The various locations are cement mill, packing plant, mix storage, kiln, clinker extraction and raw mill section. Data on particulate pollutant concentrations for the year 2010 and 2011 were obtained. Lower particulate concentrations were obtained in the year 2010 due to proper adoption of the control strategies and usage of higher efficiency bagfilters. Arguably, all the results obtain for this year are below the World Health Standard and Nigerian Federal Ministry of Environmental Standard of annual average values of 260 and $500 \mu \mathrm{g} / \mathrm{Nm}^{3}$. Conversely, higher values of particulate pollutant concentrations were obtained for the year 2011. Though, the maximum value of $448.16 \mu \mathrm{g} / \mathrm{Nm}^{3}$ recorded in the year 2011 is below the Nigerian Federal Ministry of Environmental Standard but it is an indication of improper adoption of the control strategies and lack of maintenance on the dust capturing devices. Results obtained from the cement plant show that Obajana Cement Plc operates below the Nigerian acceptable limits on particulate matter concentration.

\section{Acknowledgement}

Special thanks go to my parent Mr. Musa Jinadu Otaru and Mrs. Habibat Otaru, my Uncle Dr. Suberu M. Otaru and his wife Hajia Khadijat Otaru and Zeno Karl Schindler Foundation, Viganello-Switzerland, whom are the major pillars for creating a conducive atmosphere toward this work. 


\section{References}

[1] Abdulkareem, A.S. and Odigure, J.O. (2009). Predictive Model for Pollutant Dispersion from Gas Flaring: A Case Study of Oil Producing Area of Nigeria. Energy Sources, Part A: Recovery, Utilization, and Environmental Effects, 31:12, 1004-1015.

[2] BUWAL, (1996). Schwebstaub-Messung and Gesundheitliche Bewertung. Bundesamt Für Umwelt, Wald und Landschaft. (EDS). Schriftenreihe Umwelt Nr. 270, Bern.

[3] Federal Ministry of Environmental (FMEv) Nigeria Report, 2004/www.sciencedirect.com 02/December/2011-10:45

[4] Reding, J.T. (1977). "Industrial Profile for Environmental Use": The Cement industry, Chapter 21.

[5] Reinhold, V.N. (1992). Air Pollution Engineering Manual. Air and Waste Management Association, New York.

[6] Smidth, F.L. (2006). Cement Making Process.”Obajana Cement Plc. Lokoja, Kogi State, Nigeria.

[7] U.S. EPA, (2004). United State Environmental Protection Agency. Inventory of U.S Greenhouse Gas Emissions and Sinks. Washington, D.C. EPA 430-R-04-003.

[8] WBCSD, (2005). World Business Council for Sustainable Development. Cement Sustainability Initiative. Draft for Discussion, PP 17. 